\title{
The Impact of Smartboard on Preparatory Year EFL Learners' Motivation at a Saudi University
}

\author{
Waqar Ahmad (Corresponding author) \\ University of Jeddah, Jeddah, Kingdom of Saudi Arabia \\ E-mail: waqar22@gmail.com \\ Zuraina Ali \\ Center for Modern Languages and Human Sciences, Universiti Malaysia Pahang, Pekan Campus, Pahang, Malaysia \\ E-mail: zuraina@ump.edu.my \\ Muhammad Aslam Sipra \\ King Abdulaziz University, Jeddah, Kingdom of Saudi Arabia \\ E-mail: makhan6@kau.edu.sa \\ Imtiaz Hassan Taj \\ University of Jeddah, Jeddah, Kingdom of Saudi Arabia \\ E-mail: imtiaz468ht@gmail.com
}

Doi:10.7575/aiac.alls.v.8n.3p. 172

URL: http://dx.doi.org/10.7575/aiac.alls.v.8n.3p.172
Received: 11/04/2017

Accepted: 23/06/2017

\begin{abstract}
Smartboards, which are now widely used in the teaching and learning process in Saudi Arabia, have turned the traditional environments of the classrooms, especially the EFL classrooms to be more interesting and encouraging. Literature reviews suggest that Saudi students usually lack motivation for studying English as a foreign language. This study tends to investigate the impact of Smartboards on preparatory year EFL learners motivation at a Saudi university. Two intact groups were selected, in which one was termed as experimental and the second as control group. The experimental group was taught using the Smartboard while the control group was taught with the traditional whiteboard, pen and book method. The treatment was given for seven weeks. A questionnaire was administered to both the groups at the beginning and the end of the study. The data was analysed using the SPSS and the results showed that there was significant difference between the experimental and control groups in terms of motivation.
\end{abstract}

Keywords: Smartboard; Motivation; Saudi EFL learners

\section{Introduction}

Modern days' technological gadgets have largely changed our lifestyles and these are also widely used for academic and research purposes. Farooq and Javid (2012) have truly indicated that technology which is an outcome of education is now redefining education. There has been a growing interest in the use of computers and technologies in education in general and second or foreign language teaching and learning in particular. The fact that modern day technologies have gained recognition globally for their success in supporting second language acquisition, Saudi Arabian government aims to provide most educational institutions with modern equipment for integrating technology into the classrooms. One such advancement is the addition of Smartboards in the English language classrooms. There has been an increasing interest in utilizing SmartBoards in classrooms as this technology is perceived as combining all pre-existing instructional aids such as chalkboard, whiteboard, television, video, overhead projector, CD player, and computer (Yáñez \& Coyle, 2011). Even though the Smartboard technology is relatively a new phenomenon as it was originally designed for commercial settings (DiGregorio \& Sobel-Lojeski, 2010), it is increasingly utilized in language classrooms all over the world. As also indicated by Coyle, Yanez, and Verdú (2010), it provides second or foreign language teachers with many opportunities to teach in innovative, stimulating and promising ways that go far beyond the possibilities of traditional boards. On these grounds, it can be argued that Smartboards are now a fact of everyday life as governments, and educational institutions administrations also perceive them as a necessary gadget to have advanced technology in the classrooms (Hockly, 2013).

Since the advent of 21st century, computers and technologies have significant role in the field of English language teaching and learning. A number of studies have been done concerning the role of different technologies in ELT and that how it affects the development of language. It has been found by researchers that the use of technology inside or outside the EFL classroom tends to make the class more interesting. The researchers have also suggested that using a variety of technological materials has been shown to increase student interest and motivation. The latter i.e. motivation plays a significant role in the process of successful and effective English language teaching and learning, as MacIntyre, MacKinnon, and Clément (2009) has described it as the engine that drives the system. 
Literature reviews have indicated that English language has been of considerable importance, for scientific, social, and economic development in Kingdom of Saudi Arabia (Javid, Al-Thubaiti \& Uthman, 2013; Javid, Farooq \& Gulzar, 2012; Khan, 2011a Khan, 2011b). Mahboob and Elyas (2014) have rightly called it a topic 'loaded with political, religious, social, and economic overtones'. It has also acquired the status of a mandatory foreign language in Saudi Arabian educational domain. The Ministry of Education in Saudi Arabia has enforced English as a medium of instruction for all sciences departments in the public and private sector universities. And thus, all the major universities of Saudi Arabia have established new departments, centres or institutes to run Preparatory Year Program (PYP) for their students where the students of all disciplines are required to study English language up to Intermediate level. However, the PYP program that has been established in all the major universities of the kingdom could not be as fruitful as was expected. One major reason that has been found for the disastrous situation is the students' lack of motivation to study English language because of various cultural, traditional and religious reasons. Khan (2011a) stated that even though the Ministry of Higher Education and Saudi Arabian Universities have made exceptional ventures about purposive curriculum, suitable textbooks, qualified teachers and effective administration, but the process of English language teaching failed to deliver the required results to such an extent that (Khan, 2011a) has pronounced it as 'ineffective... and unsatisfactory'.

Among all the factors mentioned above, motivation plays a significant role in the process of successful and effective English language teaching and learning as Dörnyei and Ushioda (2011) considers it as one of the major factor in the process of second/foreign language accomplishment. Keeping in view the importance of motivation and the fact that language teaching is changing because of the immense use of the technology inside and outside of the classroom, this study tends to investigate the impact of Smartboards use on preparatory year EFL learners' motivation at a Saudi university. EFL teachers at the Saudi university are expected to utilize and maintain technological tools such as Smartboards in their classrooms to better help and engage their students. Teachers are provided with professional development centred on the use of technology and teachers are seen as up to date in their instructional strategies if they can effectively integrate technology into their classrooms. While many strategies are used to generate student motivation, technology is often referred to most and additional research may inform that practice. The extensive use of technology and especially the Smartboard in the field of ELT in the Arab world, especially the Kingdom of Saudi Arabia has inspired the researcher to analyse the role of Smartboard for EFL learners to find out what role does the Smartboard play in motivating the EFL learners.

\section{Literature Review}

With the advancement of technology and the fact that technology has been incorporated into each and every field of life (Alsied \& Pathan, 2013), it is also pertinent to equip our educational system with such technologies and encouraging efforts have been made in this regard. One such technological tool is the introduction of Smartboard. Over the period of time, this innovative technology has been admired and appreciated by students and teachers. The Smartboard has circled a typical classroom into a stimulating and encouraging learning environment (Hockly, 2013).

As mentioned by several researchers (De Vita, Verschaffel, \& Elen, 2014; Ersoy \& Bozkurt, 2015; Rajabi \& Khodabakhshzadeh, 2015; Türel \& Johnson, 2012) there are many different types of Smartboards available in the market, with different hardware and software features, but in simple words they can be described as the computer system that is connected to the data projector, a board and other related tools that present and depict the educational contents with its multimedia features to the students in an interactive and collaborative way. Generally the board screen is touch-sensitive with its interactive features but some of these devices are designed to have a pen and software comprised of dragging and dropping abilities which could be functioned by the use of a finger. The most dominant feature of the Smartboard is the presentation of images, videos; audios, animations, colors, and zooming that make the lessons more appealing and engaging for the learners and students in the EFL classrooms. Thus the Smartboard supplements classrooms in several ways by providing hands on collaboration and building the perfect learning situation.

Smartboards are found to be more helpful in the teaching and learning process. For instance, with the help of Smartboards, the teachers could be able to use the technology in a better mode; to exploit a wide range of web-based resources, and also to help them save a lot of time by saving and later on printing the transcripts and notes that they create during the lesson (Hockly, 2013; Hüseyin, 2014). Several researchers have also documented that with the help of Smartboards students could be best involved during the lesson, thereby developing their personal and social skills and also the creativity (Millum \& Warren, 2014; Türel \& Johnson, 2012; Yang \& Teng, 2014). Thus, the Smartboards have the potential to increase student enjoyment and motivation, to provide more opportunities for student participation and cooperation (Torff \& Tirotta, 2010; Turel, 2010; Türel \& Johnson, 2012).

Despite the several advantages of Smartboards in English language classrooms, as discussed above, there are also various problems that the use of Smartboards may create in English language teaching and learning. Some of these difficulties as mentioned by Alghamdi (2015) and Thomas and Schmid (2010) consist of operational problems such as the breaking down of Smartboards; and the extraordinary price of Smartboards. Schmid (2007) deliberates the EFL teachers' role as most important in the effective use of the Smartboards in the classroom and the lack of it might cause disruption. The teachers need additional time to create and consolidate all the available resources as suggested by Hall and Higgins (2005) and Smith, Higgins, Wall, and Miller (2005).

Although all of these problems and challenges mentioned above need planning and organization on part of both the teacher and the educational institution, however, one of these problems that is more serious and needs careful attention is the teachers' training to use the Smartboards professionally and efficiently. Ersoy and Bozkurt (2015) deliberates that 
language teachers need specialized training for using Smartboards successfully seems very significant in order to attain the maximum of this technology. Indeed, teachers must be proficient and well-trained in using Smartboards as mentioned by Betcher and Lee (2009). They further state that successful teaching with the help of Smartboards requires that the teacher must be prepared, collaborative, malleable, productive, enthusiastic to impart their knowledge, openminded, and prepared to design teaching and learning procedures.

The Smartboards are frequently related with the interest and motivation among students and teachers in the classrooms. A critical review of the literature on the introduction of Smartboards as a pedagogical tool in the educational settings as documented by Smith et al. (2005) indicates the Smartboard play a significant role in positive approach and attitude of the learners because of its easiness of use and the flexibility. The research also indicated that learners favoured the Smartboards technology as they considered the use of computer keyboard and mouse to be difficult and much more demanding. Similar findings were reported by the research study conducted by Moss et al. (2007) which ascertains that both the teachers and learners in classrooms have generally favourable attitudes towards the use of the Smartboards technology. A majority of the subjects included in the study related their increase in interest and motivation with the improved quality of presentation of the educational content. However, these studies are based on the views of the teachers and learners and there is inadequate evidence to identify the actual impact of these technologies on the learners' motivation.

A great deal of research about the use of Smartboards technology use in the language classrooms has been conducted to consider the learners and teachers perceptions. For instance, a study by Mathews-Aydinli and Elaziz (2010) has been carried out to ascertain the attitudes and beliefs of EFL learners and teachers on the use of Smartboards in the EFL classrooms. Researchers have reported that both the students and teachers have shown positive attitudes towards the use of Smartboards technology. The teachers and the students ensured strong belief about the usefulness of this technology and thus recommended the extensive use of this technology in the teaching and learning process. However, it is important to note that the study collected the data through the use of questionnaire and no treatment has been given to the students.

A similar kind of study was conducted by Durán and Cruz (2011) and they have concluded that when the teachers used the Smartboard technologies' during their lessons were more liked by the learners as the learners marked those lessons to be thrilling and exciting and that learners were feeling more motivated. Yet, the use of the Smartboard in the study was exploited for the selected tasks and not for the whole duration of the treatment.

The essential and crucial benefit of the Smartboard as mentioned by researchers (Schmid \& Schimmack, 2010; Turel, 2010; Xu \& Moloney, 2011) is its ability to provide creative, striking and diverse instructional materials that could help boost the motivation and enabling students' involvement and engagement in the EFL classrooms. Similar findings were also mentioned by Barber, Cooper, and Meeson (2007) in their study. These authors indicated that the Smartboards technology when utilized in the classrooms, helped to boost, motivate and encourage the learners.

Yáñez and Coyle (2011) have explored the learners' perceptions of learning with Smartboards technology in the classrooms. They conducted a survey study that focused on an English language immersion classroom in a British primary school in Spain. The results of the study specified that children preferred to interact more with the Smartboard and that its' properties were significant and engaging for the students particularly the non-native speakers. However, it should be noted that the study involved the primary school children, whereas the current study involves adult EFL learners who have completed their high school.

Several studies conducted to understand the role of Smartboard have revealed positive attitudes of the teachers and students (Jelyani, Janfaza, \& Soori, 2014; Rajabi \& Khodabakhshzadeh, 2015). The researchers have also suggested that it increases interest and motivation among students and teachers (De Vita et al., 2014; Hockly, 2013). However, a thoughtful review of the available literature has revealed the point that these studies have been more focused on the teachers and students perceptions, the evolution of teachers' pedagogical styles, and the value of Smartboards in the teaching and learning process (Balta \& Duran, 2015; Ersoy \& Bozkurt, 2015; Jelyani et al., 2014; Rajabi \& Khodabakhshzadeh, 2015). The researcher was unable to locate any studies that would investigate the effect of the Smartboards in the EFL classrooms.

Saudi students in general, face a lack of motivation for English language learning and there have been several studies in the literature reporting this fact and also the investigations to find out the causes or reasons for the lack of motivation such as Mahboob and Elyas (2014), Al-Khairy (2013), Aldosari (2014), Bakar, Sulaiman, and Rafaai (2010). A careful study of the available literature at Saudi universities reveals that the role of motivation and the effect of Smartboard on EFL learners' motivation have not been thoroughly investigated. Even, no such research has been found in the reviewed literature that corresponds with investigating the effect of Smartboard on EFL learners' motivation while learning English as a foreign language. This was the motivation behind the present study.

The present study has been designed to investigate the effect of Smartboard on EFL learners' motivation while learning English at a Saudi University, from EFL learners' perspective. This study, thus, tends to be comprehensive in nature as it focuses on the subjects' real experiences. The researcher has aimed to present first-hand information about the use of Smartboard in the EFL classroom, and thus research will be useful for the new EFL Instructors and teachers at universities in Saudi Arabia, to adept these technologies in their classroom according to the needs of their students and learners. 


\section{Research Questions}

The key research question under investigation in this study is: How does SmartBoard have an impact on the motivation of Saudi EFL learners on the preparatory year program at a public sector university? This question can be divided into the following sub-questions:

1. Is there any significant difference between the mean score of the Experimental group and Control group in the pre-treatment survey results, in terms of motivation?

2. Is there any significant difference between the mean score of the Experimental group and Control group in the post-treatment survey results, in terms of motivation?

3. Is there any significant difference between the mean scores of the Experimental group in the pre-treatment survey results and that of the same group on the post-treatment survey results, in terms of motivation?

4. Is there any significant difference between the mean scores of the Control group in the pre-treatment survey results and that of the same group on the post-treatment survey results, in terms of motivation?

\section{Methodology}

Cresswell (2012) states that in education many experimental situations occur in which researcher need to use intact groups. This might happen because of the availability of the participants or because the settings prohibits forming artificial groups. In an experimental study, the researcher look at the effects of at least one independent variable on one or more dependent variable, and at the end, the researcher want to see whether the treatment has made a difference. Thus, in this study, a non-randomised control group, Pre-test-Post-test Design will be considered the most suitable, to study the effect of SmartBoard on preparatory year EFL learners' motivation at a Saudi university. And for this purpose a questionnaire specifically designed for this study was administered before and after the treatment to find out any differences between the Experimental and the Control group in terms of motivation. Ary, Jacobs, Sorensen, and Walker (2013) consider it one of the most widely used quasi-experimental designs in educational research.

Two intact groups (each group comprised of about 30 students) of Preparatory Year Program students enrolled in PreIntermediate level were selected for the study. As the study used the groups that have already been formulated by the administration, therefore, all students in those particular classes were included in the study. Thus, 31 students were involved in Experimental group while another 30 students were involved in Control group.

Research was conducted in the English Language Unit (ELU) of a public sector university in Kingdom of Saudi Arabia. The ELU runs the Preparatory Year Program (PYP) catering to the English language learning needs of all the students that enrol in the university. The ELU provides intensive instruction of English as a Foreign Language to Preparatory Year students in order to enhance their English language skills and facilitate their academic progress. The ELU has adopted a curriculum that has been specifically designed by a British University to make it culturally acceptable to be taught at the Saudi university. The course has been divided into four parts, each being taught for the duration of seven weeks, and these have been termed as Beginners, Elementary, Pre-Intermediate, and Intermediate level. Two sections of the Pre-Intermediate level students were chosen for this research study for both the experimental and control groups. In total, 61 EFL learners were involved in the study, 31 in the experimental group and 30 in the control group.

The same textbook was used to teach both the groups. The students have 18 credit hours of their English classes every week, which is about 3 and a half hour every day. Before the students are admitted to the university, they have also studied English language courses for about six years in their secondary schools. And to get admitted they also have to appear in a placement test which helps stream the students into suitable levels.

A questionnaire was administered to both of the groups at the beginning of the research. After the questionnaire, the treatment was administered to the experimental group only while control group was taught through the traditional method. SmartBoard was used to teach the textbook to the Experimental group. Smartboard, that is perceived as combining all pre-existing instructional aids such as chalkboard, whiteboard, television, video, overhead projector, CD player, and computer (Yáñez \& Coyle, 2011) provides English language teachers with many opportunities to teach in novel, exciting and promising ways that go far beyond the possibilities of traditional boards. The treatment was continued for the seven weeks and after the treatment the same questionnaire was administered to both the groups again.

The study investigated its four research questions by using questionnaire for EFL learners'. The researcher reviewed several questionnaires provided in the studies by Al-Khairy (2013) and Vandewaetere and Desmet (2009). Further, the researcher also took guidelines from Dörnyei and Ushioda (2011) where a number of research instruments investigating motivation have been provided. Additionally it also includes a list of publications containing questionnaires and interview guides.

The questionnaire has been divided into six segments. It included 46 statements designed according to the six-point Likert scale, keeping in view the consideration that Asian students tend to use the mid-point more often (Chen, Lee, \& Stevenson, 1995). All the subjects were demanded to circle the suitable response ranging from strongly disagree to strongly agree. To enable the EFL learners with the understanding of the statements provided in the questionnaire, it was translated into their native language Arabic with the help of two colleagues whose mother tongue is Arabic and also has good command of English. Thus the Arabic version of the questionnaire was administered to both the Control Group and Experimental Group, before and after the treatment. The questionnaire was validated for construct, content 
and face validity by three colleagues of the researcher and the proposed changes were made before the administration of the questionnaire. Further, to check the reliability of the EFL learners' questionnaire, Cronbach's Alpha reliability test was run to determine inter-item consistency of the instrument and was found to be reliable $(\alpha=0.911)$.

\section{Data Collection}

In order to collect the data, a questionnaire was designed by the researcher. Two intact groups of the Preparatory Year Program students, who were enrolled in Pre-Intermediate level, were selected for the study and they were randomly assigned to Experimental and Control groups. The questionnaire was administered in the beginning of the module, which lasts for seven weeks, and the students are promoted to the next level only if they pass the examination conducted at the end of the module in eighth week. The same textbook was used to teach both the groups but the Experimental group was taught with SmartBoard while the Control group was taught with the traditional whiteboard and pen method. The treatment continued for seven weeks, and at the end of the treatment, the questionnaire was administered again with both the groups. The data collected through the questionnaires was analyzed through the Statistical Packages for Social Sciences (SPSS) for Windows v20. The reliability of the questionnaire was found out through Cronbach's alpha ( $\alpha=$ 0.911). Thus the questionnaire was found to be highly reliable. Independent Samples t-test was run to compare the means of the two groups.

\section{Results and Analysis}

The following results developed from the statistical analysis of the data. Table 1 show the comparison of the experimental group and the control group on the Pre-treatment survey results of the EFL learners at a Saudi university. The statistical analysis demonstrates that there is no significant difference between their pre-treatment questionnaire responses in terms of motivation.

Table 1. Results of independent sample t-test of the Pre-treatment survey results

\begin{tabular}{lccccc}
\hline & $\mathrm{N}$ & Mean & $\mathrm{S}$ D & $\mathrm{t}$ & Sig. \\
\hline Experimental Group & 31 & 3.3015 & .43263 & .123 & .903 \\
Control Group & 30 & 3.2884 & .40105 & & \\
\hline
\end{tabular}

The mean score of the experimental group (3.3015) is slightly higher than the mean score of the control group (3.2884) but the difference is not significant at 0.05 level $(\mathrm{p}=0.903>0.05)$, therefore it can be concluded that both the groups were at almost the same level before the treatment.

To further verify that both the groups were at the same level, Levene's test for equality of variances was also conducted to see that the group variances were equal or not. A Levene's test verified the equality of variances in the samples (homogeneity of variances) ( $\mathrm{p}=0.05)$ (Einspruch, 2005; Pallant, 2011).

Table 2. Levene's Test for Equality of Variances

\begin{tabular}{|c|c|c|c|c|}
\hline \multicolumn{5}{|c|}{ Levene's Test for Equality of Variances } \\
\hline & & & $\mathrm{F}$ & Sig. \\
\hline \multirow{2}{*}{$\begin{array}{l}\text { Pre-treatment } \\
\text { results }\end{array}$} & \multirow[t]{2}{*}{ survey } & Equal variances assumed & .046 & .830 \\
\hline & & Equal variances not assumed & & \\
\hline
\end{tabular}

The results showed ( $p=.830$, with $\alpha=0.05$ ) which means that variances were homogeneous. These results were very important for the study as it confirmed the assumption that the two groups i.e. experimental and control groups were having the same level of motivation at the commencement of the study. Thus the differences in the motivation of the experimental and control group at the end of the study could easily be evaluated.

Table 3 show the comparison of the experimental group and the control group on the Post-treatment survey results of the EFL learners.

Table 3. Results of independent samples t-test of the post-treatment survey results

\begin{tabular}{cccccc}
\hline & $\mathrm{N}$ & Mean & SD & $\mathrm{t}$ & Sig. \\
\hline Experimental Group & 31 & 3.6431 & .22047 & 3.674 & .01 \\
Control Group & 30 & 3.4000 & .29231 & & \\
\hline
\end{tabular}


The statistical analysis demonstrates that there is a significant difference between their post-treatment questionnaire responses in terms of motivation. The mean score of the experimental group (3.64) is higher than the mean score of the control group (3.40). The difference is significant at 0.05 level $(\mathrm{p}=0.01<0.05)$, therefore it can be concluded that use of Smartboard has an impact on the motivation of EFL learners at a Saudi university.

These results are in line with the studies conducted by (Türel \& Johnson, 2012) and (Durán \& Cruz, 2011). But as mentioned earlier, these studies used the Smartboard only for a limited number of activities or only for the primary school children. The results of the current study confirm that Smartboards if used effectively in the classrooms could facilitate learning and instruction in the EFL classrooms. Their regular and systematic use by the teachers as suggested by Hockly (2013) and Türel and Johnson (2012) in their classrooms could facilitate, encourage and involve the learners in the language classroom.

Table 4. Detailed analysis of the Experimental and Control group on the Post-treatment survey results

\begin{tabular}{|c|c|c|c|c|c|c|}
\hline Elements & Group & $\mathrm{N}$ & Mean & SD & $\mathrm{t}$ & Sig. \\
\hline \multirow[t]{2}{*}{ Saudi EFL Learners' Motivation } & Experimental & 31 & 3.7944 & .45248 & 4.257 & .001 \\
\hline & Control & 30 & 3.3000 & .45438 & & \\
\hline \multirow[t]{2}{*}{ Integrative Orientation } & Experimental & 31 & 3.6590 & .47478 & 1.800 & .041 \\
\hline & Control & 30 & 3.4095 & .50229 & & \\
\hline \multirow[t]{2}{*}{ Instrumental Orientation } & Experimental & 31 & 3.7097 & .40843 & 2.958 & .02 \\
\hline & Control & 30 & 3.3815 & .45736 & & \\
\hline \multirow[t]{2}{*}{ Linguistics Self-Confidence } & Experimental & 31 & 3.6815 & .45281 & 1.794 & .038 \\
\hline & Control & 30 & 3.4667 & .48238 & & \\
\hline \multirow[t]{2}{*}{ Self-efficacy beliefs } & Experimental & 31 & 3.4892 & .55266 & .581 & .564 \\
\hline & Control & 30 & 3.4000 & .54565 & & \\
\hline \multirow[t]{2}{*}{ Ought-to L2 self } & Experimental & 31 & 3.4798 & .55160 & .255 & .079 \\
\hline & Control & 30 & 3.4458 & .48655 & & \\
\hline
\end{tabular}

Table 4 illustrates a detailed analysis of the experimental and control group and demonstrate the differences between the post-treatment questionnaire responses in terms of motivation of the two groups.

a. Saudi EFL Learners' Motivation: The comparison of the experimental and control group shows that there is a difference between the post-treatment questionnaire responses in terms of Saudi EFL learners' motivation. The mean score of the experimental group (3.79) is higher than the mean score of the control group (3.30). The statistical analysis of the results shows that the difference is significant at .05 level as $(\mathrm{p}=0.01<0.05)$.

b. Integrative Orientation: The comparison of the experimental and control group shows that there is a difference between the post-treatment questionnaire responses in terms of integrative motivation. The mean score of the experimental group (3.65) is higher than the mean score of the control group (3.40). The statistical analysis of the results shows that the difference is significant at .05 level as $(\mathrm{p}=0.041<0.05)$.

c. Instrumental Orientation: The comparison of the experimental and control group shows that there is a difference between the post-treatment questionnaire responses in terms of instrumental motivation. The mean score of the experimental group (3.70) is higher than the mean score of the control group (3.38). The statistical analysis of the results shows that the difference is significant at .05 level as $(\mathrm{p}=0.02<0.05)$.

d. Linguistics Self-Confidence: The comparison of the experimental and control group shows that there is a difference between the post-treatment questionnaire responses in terms of linguistics self-confidence. The mean score of the experimental group (3.68) is higher than the mean score of the control group (3.46). The statistical analysis of the results shows that the difference is significant at .05 level as $(\mathrm{p}=0.038<0.05)$.

e. Self-efficacy beliefs: The comparison of the experimental and control group shows that there is a difference between the post-treatment questionnaire responses in terms of self-efficacy beliefs. The mean score of the experimental group (3.48) is slightly higher than the mean score of the control group (3.4) but the statistical analysis of the results shows that the difference is not significant at .05 level as $(\mathrm{p}=0.564>0.05)$.

f. Ought-to L2 self: The comparison of the experimental and control group shows that there is a difference between the post-treatment questionnaire responses in terms of ought-to L2 self. The mean score of the experimental group (3.47) is slightly higher than the mean score of the control group (3.44) but the statistical analysis of the results shows that the difference is not significant at .05 level as $(p=0.079>0.05)$.

Therefore, it can be concluded that there is significant difference between the mean scores of the experimental group (taught with Smartboards) and that of the control group (taught with traditional methods. Although the results of the 
current study show that there is significant difference between the mean score of the experimental and control groups, yet it should also be noted that the motivation is a long and tedious process. And as Dornyei and Ushioda (2009) have mentioned that it begins with a need, and ultimately take the individual to a point where he/she changes his/her behavior in order to achieve his/her desired goal. Another important aspect that should also be considered is the fact that motivation is often investigated in terms of more leaning (Dornyei, 2005). However, this study tends to investigate the effect of Smartboard on EFL learners' motivation, in terms of their positive attitude towards the Smartboard. In this regard, studying the effectiveness of the Smartboard and its implications might provide a more comprehensive understanding of the issue under discussion.

Table 5. Results of independent samples t-test of the Experimental group comparing pre-treatment and post-treatment survey results

\begin{tabular}{llllll}
\hline & $\mathrm{N}$ & Mean & SD & t & Sig. \\
\hline Pre-treatment questionnaire responses & 31 & 3.3015 & .43263 & 3.916 & .03 \\
Post-treatment questionnaire responses & 31 & 3.6431 & .22047 & \\
& & & & & \\
\hline
\end{tabular}

Table 5 illustrates the results of the independent sample t-test of the experimental group on the pre-treatment questionnaire responses and post-treatment questionnaire responses. The statistical analysis of the same group, before and after the treatment reveals that there is a difference between the pre and post-treatment questionnaire responses of the experimental group in terms of motivation. The mean score of the experimental group on the post-treatment questionnaire responses (3.64) is higher than the mean score of the same group on pre-treatment questionnaire responses (3.30). The difference is significant at .05 level $(\mathrm{p}=0.03<0.05)$. This means that there is significant difference between the mean score of the experimental group on the pre-treatment and post-treatment questionnaire responses in terms of motivation.

Table 6. Results of independent samples t-test of the Control group comparing pre-treatment and post-treatment survey results

\begin{tabular}{cccccc}
\hline & $\mathrm{N}$ & $\mathrm{Mean}$ & $\mathrm{SD}$ & $\mathrm{t}$ & $\mathrm{Sig}$ \\
\hline Pre-treatment questionnaire responses & 30 & 3.2884 & .40105 & 1.232 & .223 \\
Post-treatment questionnaire responses & 30 & 3.4000 & .29231 & & \\
\hline
\end{tabular}

Table 6 illustrates the results of the independent sample t-test of the control group (taught with traditional method) on the pre-treatment questionnaire responses and post-treatment questionnaire responses. The statistical analysis of the same group before and after the treatment reveals that there is a difference between the pre and post-treatment questionnaire responses of the control group in terms of motivation. The mean score of the control group on the posttreatment questionnaire responses (3.40) is slightly higher than the mean score of the same group on pre-treatment questionnaire responses (3.28). However, the difference between pre-treatment questionnaire responses and posttreatment questionnaire responses is not significant at .05 level $(\mathrm{p}=0.223>0.05)$. This means that there is no significant difference between the mean score of the control group on the pre-treatment and post-treatment questionnaire responses in terms of motivation.

\section{Conclusion}

The purpose of the study was to investigate the impact of the Smartboard on EFL learners' motivation at a Saudi university. The results of the study indicate that the students in the experimental group, who were taught with the Smartboard, showed a higher level of motivation than the students in the control group who were taught with the traditional method. It should also be noted that the present study involved only two groups of the students. To investigate the issue in more details, a large sample of the students could be involved in the future to better understand the impact of the Smartboards on EFL learners' motivation.

\section{References}

Al-Khairy, M. H. (2013). English as a foreign language learning demotivational factors as perceived by Saudi undergraduates. European Scientific Journal, 9(32), 365-382.

Aldosari, H. S. (2014). The entwined effects of attitude, motivation and gender on EFL learning: A correlation study. Studies in Literature and Language, 8(1), 1-5. 
Alghamdi, A. (2015). An Investigation of Saudi Teachers' Attitudes towards IWBs and their Use for Teaching and Learning in Yanbu Primary Schools in Saudi Arabia. International Journal of Arts and Sciences, 8(6), 539-554.

Alsied, S. M., \& Pathan, M. M. (2013). The use of computer technology in EFL classroom: Advantages and implications. International Journal of English Language and Translation Studies, 1(1), 61-71.

Ary, D., Jacobs, L., Sorensen, C., \& Walker, D. (2013). Introduction to Research in Education. (9th Edition). USA: Wadsworth Cengage Learning.

Bakar, K. A., Sulaiman, N. F., \& Rafaai, Z. A. M. (2010). Self-Determination Theory and motivational orientations of Arabic learners: A principal component analysis. GEMA Online Journal of Language Studies, 10(1), 71-86.

Balta, N., \& Duran, M. (2015). Attitudes of students and teachers towards the use of interactive whiteboards in elementary and secondary school classrooms. TOJET: The Turkish Online Journal of Educational Technology, 14(2), $15-23$.

Barber, D., Cooper, L., \& Meeson, G. (2007). Learning and teaching with interactive whiteboards: Primary and early years. Exeter: Learning Matters Ltd.

Betcher, C., \& Lee, M. (2009). The interactive whiteboard revolution: Teaching with IWBs. Victoria: ACER Press.

Chen, C., Lee, S.-y., \& Stevenson, H. W. (1995). Response style and cross-cultural comparisons of rating scales among East Asian and North American students. Psychological Science(6), 170-175.

Coyle, Y., Yanez, L., \& Verdú, M. (2010). The impact of the interactive whiteboard on the teacher and children's language use in an ESL immersion classroom. System, 38(4), 614-625.

Cresswell, J. W. (2012). Educational Research: Planning, Conducting, and Evaluating Quantative and Qualitative Research (4th Edition). Boston: Pearson.

De Vita, M., Verschaffel, L., \& Elen, J. (2014). Interactive whiteboards in mathematics teaching: A literature review. Education Research International, 2014, 1-16.

DiGregorio, P., \& Sobel-Lojeski, K. (2010). The effects of interactive whiteboards (IWBs) on student performance and learning: A literature review. Journal of Educational Technology Systems, 38(3), 255-312.

Dornyei, Z. (2005). The Psychology of the Language Learner: Individual Differences in Second Language Acquisition. Mahwah, New Jersey: Lawrence Erlbaum Associates.

Dornyei, Z., \& Ushioda, E. (2009). Motivation, language identity and the L2 self. Bristol: Multilingual Matters.

Dörnyei, Z., \& Ushioda, E. (2011). Teaching and Researching: Motivation. (2nd Edition). Harlow: Pearson Education Limited.

Durán, A., \& Cruz, M. (2011). The Interactive Whiteboard and foreign Language Learning: A Case Study. Porta Linguarum, 15, 211-231.

Einspruch, E. L. (2005). An Introductory Guide to SPSS for Windows (2nd ed.). Thousand Oaks: Sage Publications, Inc.

Ersoy, A., \& Bozkurt, M. (2015). Understanding an Elementary School Teachers' Journey of Using Technology in the Classroom from Sand Table to Interactive Whiteboard. International Electronic Journal of Elementary Education, 8(1), $1-20$.

Farooq, M. U., \& Javid, C. Z. (2012). Attitude of Students towards E-learning: A Study of English Language Learners at Taif University English Language Centre. NUML Journal of Critical Inquiry, 10(2), 17-28.

Hall, I., \& Higgins, S. (2005). Primary school students' perceptions of interactive whiteboards. Journal of Computer assisted learning, 21(2), 102-117.

Hockly, N. (2013). Interactive whiteboards. ELT Journal, 67(3), 354-358.

Hüseyin, Ö. Z. (2014). Teachers' and Students' Perceptions of Interactive Whiteboards in the English as a Foreign Language Classroom. TOJET: The Turkish Online Journal of Educational Technology, 13(3), 156-177.

Javid, C. Z., Al-Thubaiti, T. S., \& Uthman, A. (2013). Effects of English Language Proficiency on the Choice of Language Learning Strategies by Saudi English-Major Undergraduates. English Language Teaching, 6(1), 35-47.

Javid, C. Z., Farooq, M. U., \& Gulzar, M. A. (2012). Saudi English-Major Undergraduates and English Teachers' Perceptions Regarding Effective ELT in the KSA: A Comparative Study. European Journal of Scientific Research, 85(1), 55-70.

Jelyani, S. J., Janfaza, A., \& Soori, A. (2014). Integration of Smart Boards in EFL Classrooms. International Journal of Education \& Literacy Studies, 2(2), 20-23.

Khan, I. A. (2011a). Learning difficulties in English: Diagnosis and pedagogy in Saudi Arabia. Educational Research, 2(7), 1248-1257.

Khan, I. A. (2011b). The Teacher of English: Pedagogic Relevance in Saudi Arabia. English Language Teaching, 4(2), 112-120. 
MacIntyre, P. D., MacKinnon, S. P., \& Clément, R. (2009). The baby, the bathwater, and the future of language learning motivation research. In Z. Dörnyei \& E. Ushioda (Eds.), Motivation, language identity and the L2 self (pp. 4365). Bristol: Multilingual Matters.

Mahboob, A., \& Elyas, T. (2014). English in the Kingdom of Saudi Arabia. World Englishes, 33(1), 128-142.

Mathews-Aydinli, J., \& Elaziz, F. (2010). Turkish students' and teachers' attitudes toward the use of interactive whiteboards in EFL classrooms. Computer Assisted Language Learning, 23(3), 235-252.

Millum, T., \& Warren, C. (2014). Sharing not staring: 21 interactive whiteboard lessons for the English classroom (2nd Edition). New York: Routledge.

Moss, G., Jewitt, C., Levacic, R., Armstrong, V., Cardini, A., \& Castle, F. (2007). The interactive whiteboards, pedagogy and pupil performance evaluation: An evaluation of the schools whiteboard expansion (SWE) project: London Challenge (Research Report 816). Retrieved from Institute of Education, University of London:

Pallant, J. (2011). SPSS Survival Manual: A step by step guide to data analysis using SPSS (4th ed.). Australia: Allen \& Unwin.

Rajabi, A., \& Khodabakhshzadeh, H. (2015). The Effect of Implementation of Smart Board on Iranian LowerIntermediate EFL Learners' Reading Comprehension and Their Intrinsic Motivation in Reading. Mediterranean Journal of Social Sciences, 6(4), 281-289.

Schmid, E. C. (2007). Enhancing performance knowledge and self-esteem in classroom language learning: The potential of the ACTIVote component of interactive whiteboard technology. System, 35(2), 119-133.

Schmid, E. C., \& Schimmack, E. (2010). First steps toward a model of interactive whiteboard training for language teachers. In M. Thomas \& E. C. Schmid (Eds.), Interactive whiteboards for education: Theory, research and practice (pp. 197-214). New York: IGI Global.

Smith, H. J., Higgins, S., Wall, K., \& Miller, J. (2005). Interactive whiteboards: boon or bandwagon? A critical review of the literature. Journal of Computer assisted learning, 21(2), 91-101.

Thomas, M., \& Schmid, E. C. (2010). Interactive Whiteboards for Education: Theory, Research and Practice. New York: IGI Global.

Torff, B., \& Tirotta, R. (2010). Interactive whiteboards produce small gains in elementary students' self-reported motivation in mathematics. Computers \& Education, 54(2), 379-383.

Turel, Y. (2010). Developing teachers' utilization of interactive whiteboards. Paper presented at the Society for Information Technology \& Teacher Education International Conference, Chesapeake, VA.

Türel, Y. K., \& Johnson, T. E. (2012). Teachers' Belief and Use of Interactive Whiteboards for Teaching and Learning. Educational Technology \& Society, 15(1), 381-394.

Vandewaetere, M., \& Desmet, P. (2009). Introducing psychometrical validation of questionnaires in CALL research: The case of measuring attitude towards CALL. Computer Assisted Language Learning, 22(4), 349-380.

Xu, H. L., \& Moloney, R. (2011). Perceptions of interactive whiteboard pedagogy in the teaching of Chinese language. Australasian journal of educational technology, 27(2), 307-325.

Yáñez, L., \& Coyle, Y. (2011). Children's perceptions of learning with an interactive whiteboard. ELT Journal, 65(4), 446-457.

Yang, J. Y., \& Teng, Y. W. (2014). Perceptions of elementary school teachers and students using interactive whiteboards in English teaching and learning. Journal of Interactive Learning Research, 25(1), 125-154. 